\title{
Monitoring of agricultural land-use
}

\author{
I. Novakovska, \\ Candidate of Sciences (Economics) \\ National Aviation University
}

The purpose. To probe features of land potential of Ukraine, principles of architecture of protection of land reserves, use of monitoring of lands, its structure, legal provision of monitoring operations in agriculture. Methods. Analysis, generalization, simulation. Results. The content is analyzed of modern land-use guidance system. Monitoring of lands of territorial communities is offered. Directions of its use are specified. Conclusions. Monitoring should be carried out by administrative-territorial principle trough dilating the content and structure of monitoring operations. In particular it touches use of legal bases of land-use and protection of lands.

Key words: land-use, monitoring, classes of lands, agricultural lands, soil, fertility.

The Earth is the only universal condition of life, the natural basis of production, the all-encompassing factor of any human activity. It is not only the general territorial condition and territorial base, but also the main means of production in agriculture and forestry. It is well-known that without land, the process of production of both agricultural and forestry products would be impossible at all.

Land differs from other means in that it does not wear out, but on the contrary, if correctly used, can constantly improve, gaining new qualities, increasing its fertility. In agricultural production, the land, besides the basis for its development, is both a subject of labor, and its main means. The foundation of intensification of agricultural production, of course, is the unique feature of the land - to constantly improve for proper use.

The Constitution of Ukraine, based on the indispensability of the land as a natural resource and mother of our wealth, quite naturally recognized it as the main national wealth that is under special protection of the state [1]. Economical, efficient, rational and ecologically safe use of the land fund and its various protection are in today's conditions one of the most urgent problems national security of the country. The provision of rational use and protection of the land has also been recognized as one of the most important tasks of the land reform, the 25th anniversary of which took place on March 15, 2016.

Ukraine has a unique land resource potential capable of supplying food needs of at least 150 million inhabitants (own population 42, 8 million). By area of agricultural land, it ranks 1st in Europe, and in area of arable land per 100 inhabitants - 4th place in the world. The level of provision of arable land in Ukraine is 5.0 - 6.3 times higher than in Germany and the United Kingdom and more than twice as much as France. In terms of chernozem, our country ranks 4th in the world after Russia, the United States, and China.

Ensuring the protection of lands as the main national wealth of the Ukrainian people, while adhering to the principle of priority of the requirements of environmental safety in the use of land as a spatial basis, natural resource and the main means of production, is aimed at preventing the unjustified seizure of agricultural and forestry land, protection against harmful anthropogenic influences, reproduction and increase of soil fertility, increase of productivity of forest land, provision of special the use of lands for nature conservation, recreation, recreation, and historical and cultural purposes [2].

The management system in the field of land use and protection, in accordance with national land legislation, also includes land monitoring, the purpose of which is to organize and monitor the state of the land fund in order to timely detect changes, assess them, avoid and eliminate the inheritance. negative processes. Land monitoring is a part of a single State information system on the state of the environment and natural resources, as well as global monitoring of the natural environment and climate, according to the international geosferrally-biosphere program "Global changes". 
Land monitoring covers national, regional and local levels. It should be carried out in the context of administrative-territorial units (Autonomous Republic of Crimea, regions, districts and cities), land categories, land tenure and land use.

At the national, regional and local levels, monitoring is linked to the administrative-territorial division. However, due to the reform of local self-government and the decentralization of power, in addition to oblasts and districts, monitoring is also essential for territorial communities. In their ownership, large areas of agricultural land of state property are transferred outside of settlements. Therefore, the monitoring of the state of land within the territory of communities in order to identify changes, assess them, avoidance and eliminate the consequences of negative processes becomes quite relevant to the task of organizing rational land use.

It is difficult to maintain monitoring at the level of the categories of land under the current conditions, because the main target value of the land of Ukraine is divided into nine categories, and land registration by categories was not conducted. The distribution of available land by land owners, land users, lands and types of economic activity was determined according to the forms of state statistical reporting (forms No. 6-Zem, 6a-zem, 6b-zem, 2-zem). In order to establish the area of agricultural land of Ukraine according to the reporting data that was before 1.1.2015, it is necessary from the amount of agricultural land users to exclude the area of the lands of the nature reserve fund and other environmental protection purposes, lands of recreational recognition - Changes etc.

According to the land reporting by 1.1.2014, the area of agricultural land was 42.7 million hectares. However, this is not the area of agricultural land as a category. The latter, according to the calculations made, is 40.46 million hectares or 2.24 million hectares lower [3]. Due to the fact that the state statistical reporting on the quantitative accounting of land was canceled, neither the area of agricultural land, nor the area of agricultural land, nor the area of agricultural land for administrative power stations was impossible to establish. From July 1, 2016, state authorities and local self-government bodies will again have information for land management and organization of rational land use with the introduction of new forms of reporting. Given the above, the object the monitoring of agricultural land should be the entire area within the specific land tenure or land use, ie land use (land tenure) as a whole, which is accounted for in the State Land Cadastre.

Within the limits of a specific administrative-territorial unit, the amount of the areas of these agricultural land holdings (land uses) will constitute agricultural land. Agricultural land, according to the Land Code of Ukraine, has land "granted for the production of agricultural products, agricultural research and educational activities, the placement of the corresponding industrial infrastructure, including the infrastructure of wholesale agricultural markets, or intended for these purposes" [2, Art. 22]. Consequently, the concept of agricultural land is determined by their main purpose - the production of agricultural products. Both research and educational activities, and the placement of appropriate infrastructure for the production of agricultural products do not have a direct relationship. Moreover, wholesale markets for agricultural products. As for forest, water, nature protection, recreational lands, located within the limits of agricultural land holdings (land use), their monitoring should be carried out within the boundaries of the land plot, as part of the earth's surface, with the rights determined in relation to it. Since forest, water, nature conservation, recreational lands, etc. can not be targeted for the purposes listed in the Code (Article 22), the more correct, in our opinion, would be to call this category of land "agricultural land", not land for agricultural purposes.

The analysis of the norms of the Land Code of Ukraine, the Law of Ukraine "On land protection", "Regulations on the state monitoring of the environment", "Regulations on monitoring land," "Regulation on monitoring of soils on agricultural lands" indicates that the content of land monitoring is limited systematic observations and searches, surveys and surveys, evaluation and development of phenomena and processes forecasts [4]. However, the implementation of the main monitoring tasks identified in Article 192 of the Land Code of Ukraine with regard to the forecast of the ecological and economic consequences of land degradation with the aim of preventing or eliminating the negative processes is impossible in the absence of legal, economic, environmental and other information necessary for this. Actual prediction of land degradation is the prognosis of the most negative phenomena that can cause land degradation as a result of water and wind erosion - flooding, landslides, waterlogging, soil compaction, land contamination with radionuclides, heavy metals, chemicals, etc. 
Agrochemical certification, survey, survey and survey, evaluation of the state of land use, processes associated with changes in the characteristics of lands and soils provided by the relevant Regulations, in the absence of materials of the legal status of land, economic indicators of agricultural enterprises, the full characteristics of land use, state organization of the territory, adherence to agronomic and environmental requirements, etc., can not be a sufficient basis for the development of appropriate forecasts.

More justified would be the organization and monitoring of agricultural land use, and not the monitoring of these lands. In the scientific literature, the term "land use" is used in the double sense. Land use is understood as a system of land use, regulated by law for different categories of land, landowners and land users, that is, their legal regime. The term "land use" also means a land mass, an area owned or used. Most often it is used to characterize the lands of a particular owner or user of land, categories and land users or the size (area) of land [3].

From the total land area of Ukraine - 60.3 million hectares, agricultural land occupies 42.7 million hectares or $70.8 \%$. The total area of all agricultural lands as of 1.1 .2015 amounted to 41.5 million hectares (68.8), of which 32.5 million hectares (53.9\%) of horses, $2.4 \%$ (4\%) of hayfields, $0,9(1,5 \%)$, pastures - 5,4 million hectares (9\%), переробки - 0,2 million hectares $(0,4 \%)$. For owners and land users, the area of agricultural land was distributed as follows: agricultural land enterprises $49.5 \%$ (of which: state 2.3), land citizens 38.2, land users of other categories - 12.3\% [5].

Under current legislation, agricultural land use, as the largest category of land in its area, has a special legal regime. This is, first of all, the priority of agricultural land use, the establishment of restrictions on the occupation of land for non-agricultural needs, the reimbursement of losses of agricultural production, associated with the withdrawal of land, special protection of soil cover, the introduction of a special regime for the use of especially valuable soils and lands, etc. These and other legal provisions should be fully applied in land monitoring.

Land for agricultural purposes in the composition of the land is divided into two groups:

- agricultural lands, which include arable land (arable land), perennial plantations, hayfields, pastures and crossings;

- non-agricultural lands, which include economic paths and runways, field-protective forest strips and other protective stands, except those that are classified in the forestry lands, land under economic buildings and courtyards, temporary conservation land, etc.

The structure of agricultural land is one of the essential indicators of ecological safety of land use. The high level of agricultural development of the territory of Ukraine (almost 69\%) and land plots (53.9\%), which is one of the highest in the world, cause excessive degradation of soil cover, low land use efficiency of sloping and other unproductive lands, and violations of the ecological sustainability of the land fund.

However, special rules for the use of different agricultural land can not be considered sufficiently developed, and measures to protect them are effective. With regard to the subject structure in relation to the use of agricultural land, the legal regime is particularly detailed for citizens. It has been established that agricultural land can not be transferred to foreigners, stateless persons and foreign legal entities. Features of transfer of ownership, granting and using land areas of the citizens are regulated separately for the conduct of a private peasant farm (Article 33 of the Code), gardening (Article 35 Code), gardening (Article 36 of the Code), hay mowing and grazing (Article 34 of the Code), as well as for the management of a farm Articles 31,32 of the Code).

However doubtful see the association in Art. 24 Code of land of state and communal agricultural enterprises, institutions and organizations engaged in commodity agricultural production, with the lands of research institutions and educational institutions, which are the basis for research and educational purposes. In the Land Code of Ukraine in 1992, for example, land of research institutions and educational institutions could not be withdrawn for non-agricultural needs in general [6]. At the moment, it now only applies to scientific research fields of scientific institutions and higher education institutions. The law provides for the consent of the Presidium of the National Academy of Sciences of Ukraine and national branch academies of sciences for the seizure of land plots of the subjects of the named academies, but this requirement is not always fulfilled. The scale of the encroachment of entrepreneurial structures in modern conditions on the ground of research facilities and other objects of academic science predetermine the need to regulate the 
land use of the experimental scientific and educational base and establish a special protection regime on the national level.

A serious problem of the legal regulation of the priority of agricultural land is abstraction from the requirements of environmental safety and the economic justification of the possibility of occupying certain or other land for non-agricultural needs. The declarative provision of Article 23 of the Code that land eligible for agricultural land should be provided, primarily for agricultural purposes, do not operate in practice. The same as the definition of these lands based on the data of the State Land Cadastre. First of all, in the inventory there is no classification of the land fund for agricultural use. For over 50 years we have not conducted solid large-scale soil surveys, and since 1996, the cadastre has no information about the qualitative accounting of land in general. There is no classification of agricultural land for specific qualitative indicators, although the soil cultivation has been repeatedly carried out, and the normative monetary valuation of agricultural lands also exists, although it is outdated.

Taking into account the principles of land legislation (Article 5 of the Code) regarding the priority of the requirements of environmental safety, the priority of agricultural land use should be based on this principle and have specific norms established by the legislation regarding optimal land parcels, qualitative state of soils, maximum permissible contamination of soil cover, indicators of land degradation and soils.

Economic levers of protection of agricultural lands should be introduced, focusing on the size of losses of agricultural production, which require improvement and revision of the principles of their establishment [7].

The Land Code of Ukraine contains the main provisions of land use of farms (Article 31 of the Code), which may consist of:

- a land plot owned by the farm as a legal entity;

- land plots owned by citizens - members of the farm for private property rights;

- a land plot used by the farmer on a lease.

Family farms should feel the constant state support and protection of their land rights, as well as the corresponding advantages in acquiring the right to lease land.

As you know, as a result of the land reform, almost $80 \%$ of the arable land has become private property of citizens. It is these owners who, in accordance with the law, must ensure the rational use and protection of land, in particular, they are obliged to increase the fertility and to preserve other beneficial properties of soils.

However, almost $90 \%$ of the land is leased by the peasants, that is, they are landlords and do not themselves use their land ownership. They only have the right to demand from the tenant that the ecological safety of land use and the preservation of soil fertility are observed. Thus, the protection of the rights of peasants - owners of land to land - is extremely relevant component of the social protection of their rights as landlords.

Compliance with the ecological safety of land use, preservation of soil fertility is largely due to the terms of land lease agreements. There is no doubt that it is economically unprofitable to invest in short-term lease of land plots to improve soil fertility, protect soil from erosion processes, and carry out cultural works. Although under the law, the cost of improving the condition of land is subject to compensation by the lessee, practice is almost not aware of such examples [8].

The differentiation of agricultural lands according to predefined indicators for assessing their quality should be carried out in a way of applying the ecological and landscape approach to land use in general. Ecological, economic and agroecological zoning and land classification should be carried out in such a way that, in economic and agroecological differentiation of land, the living requirements of plants were taken into account, the possibility of adapting agricultural crops to the existing conditions for their cultivation. Such zoning makes it possible to detail and classify the lands and landscapes of the territory, leveling off its disadvantages, which are to prioritize anthropogenic changes (altered, polluted, eroded, etc.) and the nature of human activity (field, meadow, garden, etc.). Information on ecological, economic and agroecological value and quality of agricultural land can be applied at all levels of their regulation (regional, local, economic).

Agricultural land should be restricted to: the use of certain technologies or agro-technical operations for the cultivation of crops; plowing hayfields and pastures; the use of degraded, unproductive, as well as technogenically contaminated land plots; groundless intensive use of land [9]. 
In the post-reform period, since 1991, significant changes have taken place in the structure of the country's crops, in particular due to the growth of industrial crops and the reduction of sown areas of forage crops. In the structure of crops, the share of grain and leguminous crops increased from $45 \%$ in 1990 to $54.3 \%$ in 2014. At the same time, for the specified the period of sowing area of maize for grain increased 3.8 times (from 1234 to 4691 thousand hectares). Technical crops have increased their share from 11.6 to $31 \%$. Moreover, the area of sunflower has increased by 3.2 times (to 5257 thousand hectares), and rape - 20 times [5].

The growth of areas of technical crops and maize caused a violation of crop rotation, led to a decrease in soil fertility.

The area of fodder crops unreasonably decreased by 5.7 times (from 12 to 2.1 million hectares). Attention is drawn to the fact that out of 1,193 farms with a total crop area of 2001, only about 16 farms sowed seedlings of 3000 hectares. Of the 1367 farms, the sown area of which exceeded 3 thousand hectares, only 7 farms were engaged in the cultivation of fodder crops, and from the total sown area of this group of farms (over 3 thousand hectares) - 7384.4 thousand hectares, forage crops were sown only on the 25 th area , 5 thousand hectares $(0,34 \%)$ - [5].

Consequently, farms with an area of over 3,000 hectares (including agroholdings) did not have their own livestock, and therefore did not produce or make organic fertilizers. In general, the country's organic fertilizer fell from $8.6 \mathrm{t} /$ per 1 hectare of sown area to $0.5 \mathrm{t} / \mathrm{ha}$ (table). Mineral fertilizers also significantly decreased (from $141 \mathrm{~kg}$ of nutrients in 1990 to $82 \mathrm{~kg}$ in 2014). This resulted in a negative balance of humus and nutrients in the soil (by $53 \mathrm{~kg}$ in 2014).

Under established conditions, monitoring of soils, especially of soil fertility, as well as the effects of water and wind erosion, and other factors that cause land degradation and soil cover, is of particular importance. Crisis phenomena in agricultural land use have become factors that seriously affect the national security of the state.

The official agrarian statistics quite fully characterize the land use of rural households: their distribution by area of land, the compactness of the location of land, the use of fertilizers and plant protection products, the implementation of individual management measures (uncultivated soil cultivation, liming of soils, crop rotation, irrigation of land). However, these holdings occupy a relatively small area of land (personal peasant farms and farmland account for 5.05 million hectares).

It's a shame that we do not have the same information about agricultural enterprises, especially agricultural holdings. Full usage and protection information Land is not included in the statistical directories "Agriculture of Ukraine" and in relation to farms. This creates serious difficulties for the analysis and forecasting of negative phenomena and their overcoming when conducting monitoring of agricultural land use.

The use and protection of land remain one of the priority areas of state policy in the field of food and environmental safety, nature management and environmental protection. The implementation of these areas requires the proper organization of monitoring of agricultural land use, provided that the state of the land is modernized, including the restoration of the collection of statistical data on land conservation, the allocation of the necessary amount of funds from the state and local budgets for the implementation of a set of land protection measures [10].

\section{Conclusions}

The peculiarity of the land that distinguishes it from other means of production is the ability of the land to constantly improve for proper use. The actual use and protection of the unique land resource potential of Ukraine in modern conditions does not ensure compliance with the principle of priority of environmental safety requirements in agricultural land use. Therefore, the role of land monitoring, the need to improve its territorial and categorical formation, the expansion of the composition and content of monitoring work is increasing. It is necessary to introduce monitoring of the land of the united territorial communities, to change the territorial boundaries of the objects of monitoring by the land registers, to expand the monitoring functions by incorporating into it the analysis of the legal principles of land use, the dynamics of the structural and subjective composition of lands, economic instruments of protection, ecological -economic and agroecological zoning. 


\section{Bibliography}

1. Конституція України. - К.: Преса України, 1997. - 80 с.

2. Земельний кодекс України//Відомості Верховної Ради України (ВВР). - 2002. — № 3 - 4. - С. 27.

3. Соціально-економічні проблеми сучасного землекористування/Л.Я. Новаковський, М.А. Олещенко. - К.: Урожай, 2009. - С. 108 - 109.

4. Довідник із землеустрою; за ред. Л.Я. Новаковського, 4-те вид., перероб. і допов. - К.: Аграр. наука, 2015. - С. 128 - 131.

5. Сільське господарство України. Статистичний збірник 2014 року. - К., 2015. - 380 с.

6. Земельне законодавство України. У 2-х книгах. Кн. 1-ша. - К.: Урожай, 2002. — С. 122.

7. Основи економіки землекористування/І.О. Новаковська. - К.: ВЦ «Просвіта, 2013. - С. 211 - 217.

8. Трансформація сільськогосподарського землекористування/І.О. Новаковська.

- Чернівці: Прут, 2010. - 208 с.

9. Медведев В.В. Мониторинг почв. - Х.: Городская типография, 2012. - 537 с.

10. Національна доповідь щодо завершення земельної реформи; за наук. ред. Л.Я. Новаковського. К.: Аграр. наука, 2015. - С. 30.

11. Балюк С.А. Сучасні проблеми біологічної деградації чорноземів і способи збереження їх родючості/С.А. Балюк, Б.С. Носко, Є.В. Скрильник//Вісн. аграр. науки. - 2016. - № 1. - С. 11 - 17. 